\title{
Facing Down Climate Change: Now or Never
}

It is ironic that MEDICC Review's theme issue on environment, climate change and health goes to press in April, one of the hottest on record in Cuba. Sunday, April 26 was one of the hottest days in the past five decades-and this in what is usually considered one of the country's cooler months, with summer officially beginning in June. If this is April, Cubans are saying, what will happen in July?!

April is also, of course, the month we celebrate Earth Day, which acquires particular relevance this year, when world governments must decide on new sustainable development goals and create a framework to ensure financial support for a global sustainable development agenda. In her Earth Day remarks, Mary Robinson-former president of Ireland and UN High Commissioner for Human Rights, now UN Special Envoy on Climate Change-said that 2015 is a critical year, one in which greenhouse emissions must stay "within budget" to avoid mean temperatures rising $2{ }^{\circ} \mathrm{C}$ above preindustrial levels. She emphasized the concept of climate justice, meaning an equitable sharing of the benefits and burdens of preventing climate change and mitigating its impacts. Particularly, wealthier countries whose growth has depended mainly on fossil fuels must move quickly to a sustainable development model, while committing resources to help middle- and low-income countries transition to zero-carbon development.[1]

Such a perspective of shared 'sliding scale' responsibility to achieve a just, sustainable future is vital now because, while the physical environment is a fundamental determinant of health, the social determinants strongly influence people's chances of living in a healthful or not-so-healthful environment. This is played out at individual, community, national and global levels, nowhere as starkly as in the case of climate change, whose effects may even lead to the disappearance of some small and poor developing nations. Ms Robinson cited the Pacific island Republic of Kiribati, whose government is purchasing land in Fiji, so its people will have a place to go when the seas sweep away their nation. She highlighted the need for a new development model: 2015 is the year to catalyze a transformation-away from business as usual and to a more inclusive, sustainable and just alternative.[1]

The scientific consensus is that climate change is a fact,[2] but many politicians continue to debate its existence as if it were a question of how many angels can dance on the head of a pin, and climate-change denial in many jurisdictions is hampering policy responses to the daunting challenge ahead. Meanwhile, in Cuba, climate change is a brutal fact that the country must face head on. From the creation in 1991 of the Cuban Academy of Science's Climate Change Commission to work presented in this issue on climate change and health, there have been continuing efforts and investment in creating the evidence base to inform policy decisions and programs to slow climate change, increase ability to predict extreme weather events, and to anticipate and mitigate health impacts of both long-term changes and acute events.[3]

In the next pages, we present some of the history and results of this work. Senior editor Gorry interviews two eminent

researchers at the forefront of Cuba's efforts to protect its population from climate-related health risks, Drs Guillermo Mesa and Paulo Ortiz. A Special Article by the director of Cuba's Environmental Agency and the president of the Cuban Academy of Sciences describes the current climate change picture, predictions for adverse effects on ecological systems and health, and some of the strategies in place to address these. Two related research articles are Rivero's study of climate variability's effect on acute cardiac deaths and Ortiz's description of how modeling climate data can help predict outbreaks of vector-borne diseases.

Our two Viewpoints explore relatively uncharted waters: González warns that quick-fix disaster-response decisions can lead to unintended adverse health effects and Whittle suggests opportunities for environmental protection cooperation between the USA and Cuba stemming from the prospect of renewed diplomatic ties.

MEDICC Review continues its publishing on Cuba's bout with chronic non-communicable diseases with Bohorques' study of an underutilized dialysis method in Cuba that can both extend life and improve quality of life in patients with end-stage renal disease and Peix's report on her work predicting outcomes in heart failure patients. Hernández-Triana's Perspective critiques management of factors contributing to excess weight gain in Cuban children leading to chronic diseases later in life, with particular emphasis on nutrition for full-term low birth weight infants.

\section{5 is the year to catalyse a transformation-away from business as usual and to a more inclusive, sustainable and just alternative (Mary Robinson)}

Finally, Ribot presents research on elder abuse in Cuba, findings that contribute to growing health system and intersectoral attention to domestic violence in the country-to effectively measure its extent, adopt culturally relevant and community-centered responses, and prevent its proliferation.

As we close this issue, MEDICC Review congratulates Editorial Board member, Dr Raúl Herrera and his colleagues for their research on chronic kidney disease of uncertain etiology, which last month was awarded the Cuban Academy of Sciences' highest distinction. - 1 -

\section{The Editors}

1. The Elders [Internet]. Johannesburg: The Elders; c2015. Climate justice: why is it relevant in 2015?; 2015 Apr 22 [cited 2015 Apr 28]; [about 4 screens]. Available from: http://theelders.org/article/climate-justice-why-it-relevant-2015

2. Stocker TF, Qin D, Plattner GK, Tignor M, Allen SK, Boschung J, et al, editors Climate change 2013: the physical science basis [Internet]. Geneva: Intergovernmental Panel on Climate Change; World Meteorological Organization. Available from: www.ipcc.ch/report/ar5/wg1/

3. Planos E, Rivero R, Guevara V, editors. Impacto del cambio climático y medidas de adaptación en Cuba. Havana: Ministry of Science, Technology and the Environment (CU); 2013. Chapter 10. p. 401-29. Spanish. 